\title{
Celowa pigmentacja skóry - nowe wyzwanie dla dermatologów. Sprawozdanie z IV Europejskiego Kongresu Badań nad Tatuażami i Substancjami Barwiącymi
}

\author{
Berno, 26-28 marca 2019 roku
}

Dermatol Rev/Przegl Dermatol 2019, 106, 427-428

Czwarty już kongres ECTP (the $4^{\text {th }}$ European Congress on Tattoo and Pigment Research) odbył się w tym roku 26-28 marca w Bernie w Szwajcarii. Formuła tych spotkań jest wyjątkowa. W kongresie uczestniczą zarówno lekarze, jak i naukowcy zajmujący się badaniem barwników - chemicy, biolodzy, a także przedstawiciele organizacji tatuażystów, producentów i dystrybutorów barwników do celowej pigmentacji skóry, konsumentów i pacjentów. Prelegentami są reprezentanci każdej z tych grup. Żywa dyskusja w trakcie sesji i w kuluarach świadczy o tym, jak duża jest potrzeba wiedzy i wymiany doświadczeń w tych wszystkich, czasem bardzo odmiennych, środowiskach.

W przeddzień kongresu odbyło się seminarium poświęcone nadchodzącym zmianom $w$ regulacjach prawnych dotyczących branży tatuaży. Zwrócono uwagę na konieczność standaryzacji w zakresie higieny, sprzętu używanego podczas tatuowania oraz składów substancji barwiących wprowadzanych do skóry. Ocenia się, że bezpieczeństwo zabiegu tatuowania w dużej mierze zależy od czystości chemicznej i mikrobiologicznej używanych pigmentów. Obecnie nie istnieją przepisy regulujące składy dostępnych powszechnie na rynku tuszy. Zauważono, że w wielu krajach europejskich związki chemiczne, których używanie jest zakazane przy produkcji kosmetyków, mogą być swobodnie wprowadzane do skóry podczas zabiegu tatuowania. Są to substancje, które najczęściej pod wpływem promieniowania ultrafioletowego przekształcają się w kancerogenne związki, takie jak aminy aromatyczne (anizydyna, toluidyna, benzopiren) oraz policykliczne węglowodory aromatyczne. Zanieczyszczenia tuszy metalami ciężkimi, takimi jak chrom czy nikiel, mogą prowokować reakcje alergiczne w obrębie tatuażu, natomiast zanieczyszczenia mikrobiologiczne prowadzić do powstawania infekcji miejscowych i systemowych. Amerykańska Akademia Dermatologii i Wenerologii podkreśla, że u 10\% posiadaczy celowo wykonanych zmian pigmentacyjnych na skórze występują różnego rodzaju komplika- cje zdrowotne z nimi związane. Nie ma obecnie wiarygodnych badań potwierdzających związek między tatuażem a nowotworzeniem. W trakcie konferencji poinformowano o rozpoczęciu dużego badania epidemiologicznego w Szwecji mającego na celu przeanalizowanie zależności pomiędzy tatuażami a występowaniem czerniaka, raka kolczystokomórkowego skóry oraz chłoniaków nieziarniczych. Wyniki badania zostaną zaprezentowane w 2020 roku. Wielokrotnie podkreślano także znaczenie edukacji tatuażystów na temat zmian skórnych i konieczność ich współpracy z dermatologami. Szczególną uwagę zwrócono na tatuowanie w obrębie znamion melanocytowych, co znacznie zaburza ich ocenę kliniczną oraz dermatoskopową i może prowadzić do opóźnionego rozpoznania czerniaka i innych nowotworów skóry.

Podczas sesji naukowych poruszano tematy powikłań zdrowotnych tatuowania skóry, analiz chemicznych powszechnie używanych pigmentów, wpływu egzogennych substancji barwiących na układ immunologiczny i narządy wewnętrzne, reakcji alergicznych związanych $\mathrm{z}$ wykonaniem tatuaży czasowych, wykorzystania testów płatkowych z najczęstszymi alergenami występujących w tuszach, dermatografii medycznej, makijażu permanentnego oraz wpływu tatuaży na psychikę. Jednym z poruszanych zagadnień była epidemiologia infekcji bakteryjnych, wirusowych i grzybiczych występujących w ranie po wykonanym zabiegu tatuowania skóry. Poinformowano, że większość opisanych dotychczas $\mathrm{w}$ piśmiennictwie infekcji pochodziło z nadkażeń oportunistycznymi patogenami bakteryjnymi, jednak dane, którymi dysponujemy, są znacznie niedoszacowane ze względu na niedostateczną zgłaszalność takich przypadków. Wiele uwagi poświęcono powiązaniu tatuaży z występowaniem sarkoidozy. Badacze ocenili 161 wycinków pobranych od pacjentów z reakcjami grudkowo-guzkowymi w tatuażu i doszli do wniosku, że zwiększona liczba aglomeratów czarnego pigmentu wiąże się z częstszym występowaniem sarkoidozy. Przedstawione dane wska- 
zują, że rozpoznanie sarkoidozy stanowi względne przeciwwskazanie do zabiegu celowej pigmentacji. Pojawienie się grudek i guzków w obrębie tatuażu jest wskazaniem do diagnostyki w kierunku sarkoidozy. Tatuażyści powinni unikać podaży nadmiernej ilości czarnego barwnika do skóry, także u zdrowych osób. Interesujące były również doniesienia dotyczące prób leczenia reakcji alergicznych na czerwony pigment - hydroksychlorochiną oraz cyklosporyną A, u pacjentów, którzy nie wyrazili zgody na usunięcie tatuażu bądź u których było to niemożliwe ze względu na lokalizację.

Coraz większą popularność zdobywa zabieg medycznej pigmentacji, określany także terminem „dermatografia medyczna”. Technika ta polega na zaawansowanej mikropigmentacji skóry i pozwala ukryć niedoskonałości i zmiany chorobowe, w przypadku których standardowa terapia nie pozwala osiągnąć satysfakcjonujących rezultatów. Interesująca dyskusja dotyczyła bezpieczeństwa tatuaży u chorych na łuszczycę, u których tatuaż może wywołać wysiew zmian na drodze kebneryzacji. Wydaje się jednak, że ryzyko wysiewu zmian w miejscu mikronakłuć dotyczy tylko pacjentów w aktywnym, wysiewnym okresie choroby. Wykonywanie tatuażu jest przeciwwskazane u chorych leczonych immunosupresyjnie z powodu łuszczycy. Przedstawiono ciekawe wyniki badań, w których stwierdzono pozytywny wpływ posiadania tatuażu przez osoby z łuszczycą na ich samoocenę, podkreślenie własnej indywidualności i niezależności od przewlekłej choroby. Zaprezentowano także najnowsze doniesienia statystyczne z USA, gdzie odsetek wytatuowanych osób szacuje się na około 30\%. Przebadano 501 osób posiadających tatuaże, wśród których 16\% żałowało wykonania przynajmniej jednego z nich, a $21 \%$ było zainteresowanych jego usunięciem.

Podczas odrębnej sesji poświęconej najnowszym technikom usuwania tatuaży podkreślano rolę technologii pikosekundowej, która stanowi obecnie złoty standard usuwania zmian pigmentacyjnych. Uważa się, że lasery pikosekundowe efektywniej usuwają zmiany barwnikowe oraz wymagają mniejszej liczby sesji niż lasery Q-switched, wykorzystujące technologię nanosekundową. Zaprezentowano również zastosowanie technologii HIFU (high frequency focused ultrasound) jako potencjalnie nowej metody służącej do usuwania celowo wykonanych zmian pigmentacyjnych. Według autorów metoda ta może stać się alternatywą dla technologii laserowych, jednak konieczne są dalsze badania w tym kierunku. Omawiano także najczęstsze komplikacje, które mogą wystąpić po laserowym usuwaniu tatuaży, takie jak oparzenia skóry, zmiany rumieniowe, hiperpigmentacyjne, bliznowacenie. Zwrócono uwagę na przeciwwskazania do terapii laserowej, wśród których wymieniono zmiany w teksturze skóry przed zabiegiem, atroficzne i hipertroficzne blizny, keloidy, ziarniniaki oraz odczyny alergiczne.

Kongres odbywał się w szpitalu uniwersyteckim w Bernie - mieście o wielowiekowej historii, malowniczo położonym nad rzeką Aare. Wkrótce zostanie ogłoszone miejsce kolejnego spotkania w 2021 roku. ESTP zachęca do aktywnego członkostwa w organizacji - zajmuje się ona nie tylko wsparciem badań naukowych nad tatuażami i innymi substancjami barwiącymi skórę, lecz daje także szereg bezpośrednich korzyści swoim członkom (www.estpresearch.org).

\section{Aneta Szczerkowska-Dobosz, Patrycja Rogowska Katedra i Klinika Dermatologii, Wenerologii i Alergologii Gdański Uniwersytet Medyczny}

